\title{
A Phylogenetic Analysis of Staphylococci, Peptococcus saccharolyticus and Micrococcus mucilaginosus
}

\author{
By WOLFGANG LUDWIG, ${ }^{1}$ KARL-HEINZ SCHLEIFER, ${ }^{1}$ GEORGE \\ E. FOX, ${ }^{2}$ ELKE SEEWALDT ${ }^{1}$ AND ERKO STACKEBRANDT ${ }^{1 *}$ \\ ${ }^{1}$ Lehrstuhl für Mikrobiologie der Technischen Universität München, Arcisstrasse 16, \\ D-8000 München 2, Federal Republic of Germany \\ ${ }^{2}$ Department of Biophysical Sciences, University of Houston, Houston, Texas 77004, U.S.A.
}

(Received 13 October 1980; revised 5 January 1981)

\begin{abstract}
The intra- and intergeneric relationships of the genus Staphylococcus, and the phylogenetic position of Peptococcus saccharolyticus and Micrococcus mucilaginosus (Staphylococcus salivarius), were investigated by comparative oligonucleotide cataloguing of 16S rRNA. All the staphylococci investigated form a phylogenetically coherent group at the genus level that, in addition, contains the anaerobic species Peptococcus saccharolyticus. The genus Staphylococcus belongs to the broad Bacillus-Lactobacillus-Streptococcus cluster that is defined by Gram-positive bacteria with a low DNA G+C content.

Micrococcus mucilaginosus is not a genuine member of the genus Micrococcus. The binary matching coefficients between the 16S rRNA of Micrococcus mucilaginosus and those of representatives of the Arthrobacter/Micrococcus group and related genera indicate that Micrococcus mucilaginosus should be regarded as a member of a new genus.
\end{abstract}

\section{INTRODUCTION}

Fundamental genetic and epigenetic differences exist between Staphylococcus and Micrococcus as expressed in their DNA G+C content: 31 to $36 \mathrm{~mol} \%$ for Staphylococcus, compared with 68 to $72 \mathrm{ml} \%$ for Micrococcus (Silvestri \& Hill, 1965; Kocur et al., 1971). Differences in peptidoglycan type (Schleifer \& Kandler, 1972) and in cytochrome patterns (Faller et al., 1980) as well as differences revealed by numerical taxonomic studies (Feltham, 1979) also indicate the heterogeneity of this group. Despite these distinct differences, taxonomists still include all of these catalase-positive cocci within the family Micrococcaceae (Baird-Parker, 1974). Techniques such as DNA-DNA and DNA-rRNA reassociation, and the comparative immunological analysis of homologous proteins, which measure the phylogenetic distances between organisms, have proved useful in unravelling the intrageneric relationships between species of Staphylococcus and Micrococcus (Schleifer et al., 1979a, b; Meyer \& Schleifer, 1978; Kilpper et al., 1980). These studies also strongly support the separation of Micrococcus from Staphylococcus, but fail to identify specifically the phylogenetic position of these organisms among the bacteria in general.

Recent phylogenetic investigations on members of the family Micrococcaceae using comparative oligonucleotide cataloguing of 16S rRNA (Fox et al., 1977; Woese et al., 1976; Fox et al., 1980) led to the conclusion that this taxon should be dissected (Stackebrandt \& Woese, 1979; Stackebrandt et al., 1980). All strains of Micrococcus investigated were found to be in close phylogenetic relationship to certain coryneforms, especially to Arthrobacter, Cellulomonas, Brevibacterium and Microbacterium, whereas Planococcus and Staphylococcus share a moderate but distinct relationship to the Bacillus cluster (Stackebrandt \& Woese, 1979; Fox et al., 1980). In contrast to the large number of 
micrococci investigated, only one member of the genus Staphylococcus, S. epidermidis ATCC 155, was included in these studies. To determine the genealogical relationship of the genus Staphylococcus on a broader basis, we have extended these RNA sequencing studies, using an in vitro labelling procedure (Stackebrandt et al., 1981), to several species shown by DNA-DNA reassociation studies to be only rather distantly related (Schleifer et al., 1979a). Peptococcus saccharolyticus was included because this organism was recently described as an anaerobic member of Staphylococcus (Kilpper et al., 1980). Micrococcus mucilaginosus (Staphylococcus salivarius) CCM 2417 was investigated because its DNA G+C content of $59 \mathrm{~mol} \%$ (Kocur \& Bohacek, 1974) does not fall in the usual range for either Staphylococcus or Micrococcus.

\section{METHODS}

Organisms. The following strains were obtained from the Deutsche Sammlung von Mikroorganismen (DSM) and from the American Type Culture Collection (ATCC): Staphylococcus haemolyticus DSM 20263; S. xylosus DSM 20266; S. aureus ATCC 12600; S. sciuri subsp. sciuri ATCC 29062; Peptococcus saccharolyticus ATCC 14953. Micrococcus mucilaginosus CCM 2417 was obtained from the Czechoslovak Collection of Microorganisms, Brno, CSSR. All of the strains investigated are type or neotype strains.

Preparation and sequencing of $16 S$ rRNA. Peptococcus saccharolyticus was grown anaerobically in a medium described by Kilpper et al. (1980). All other strains were grown aerobically in $200 \mathrm{ml}$ of a peptone/yeast extract/glucose broth $(0.5: 0.25: 0.5 ; \%, \mathrm{w} / \mathrm{v})$. To facilitate the rupture of the cells, about $0.5 \mathrm{mg}^{\text {penicillin } \mathrm{ml}^{-1}}$ was added to the medium during the early exponential phase of growth. After $1 \mathrm{~h}$ incubation cells were harvested by centrifugation and broken by passing through a French press in a buffer containing Macaloid (Baroid Division, National Lead Co., Houston, Texas) (Woese et al., 1976) in the presence of several drops of $15 \%$ (w/v) sodium dodecyl sulphate and $100 \mu \mathrm{g}$ Proteinase K (Merck). Phenol treatment of the crude extract, and isolation and purification of 16S rRNA, followed the methods described by Woese et al. (1976) and Stackebrandt et al. (1981). Controlled digestion of the RNA by RNAase $T_{1}$, dephosphorylation of the $3^{\prime}$ end of the oligonucleotides and the enzymic in vitro labelling of the $5^{\prime}$ end with $\left[\gamma^{32} \mathrm{P}\right]$ ATP and polynucleotide kinase were carried out according to Simsek et al. (1973) and Silberklang et al. (1979), with modifications described by Stackebrandt et al. (1981). Partial cleavage of 5'-labelled oligonucleotides by controlled alkali treatment and the determination of the nucleotide sequences by mobility shift analysis followed the description of Stackebrandt et al. (1981). Binary matching coefficients ( $S_{A B}$ values) were calculated as described by Fox et al. (1977). Dendrograms were generated from tabulations of the binary matching coefficients by average linkage (between the merged groups) clustering.

\section{RESULTS}

The oligonucleotides of the organisms investigated are listed in Table 1. The phylogenetic positions of various staphylococci and Micrococcus mucilaginosus among the Gram-positive bacteria, as derived from the comparative analysis of the 16S rRNA oligonucleotides (Fox $e t$ al., 1980), are depicted in Fig. 1. This dendrogram was calculated from the binary matching coefficients, $S_{A B}$, given in Table 2 . All the staphylococci investigated form a genetically highly related cluster which also includes Peptococcus saccharolyticus. The Staphylococcus group falls into the large Bacillus cluster (Fig. 1). The lowest $S_{A B}$ values separating these species are in the range 0.64 to 0.72 (Table 2). These values are comparable to those found within the Arthrobacter/Micrococcus group (0.69), the cellulomonads (0.72) and the group comprising Microbacterium lacticum and the plant pathogenic coryneforms (0.67). In these three cases the status of genus was recently suggested or confirmed (Stackebrandt et al., 1980). The close relationships among the species of Staphylococcus seen here also strongly support its status as a defined genus. Figure 2 shows the phylogenetic relatedness of the individual staphylococci and $P$. saccharolyticus within the cluster defined by rRNA similarities. The closest relationships are found between $S$. xylosus and $S$. haemolyticus $\left(S_{A B} 0 \cdot 85\right)$, and between $S$. aureus and $S$. epidermidis ATCC $155(0.84)$. These pairs of organisms exhibit an average $S_{A B}$ value of 0.81 . Peptococcus saccharolyticus falls into the Staphylococcus cluster $(0.75)$ in which $S$. sciuri is the most distantly related organism (0.69). Micrococcus 


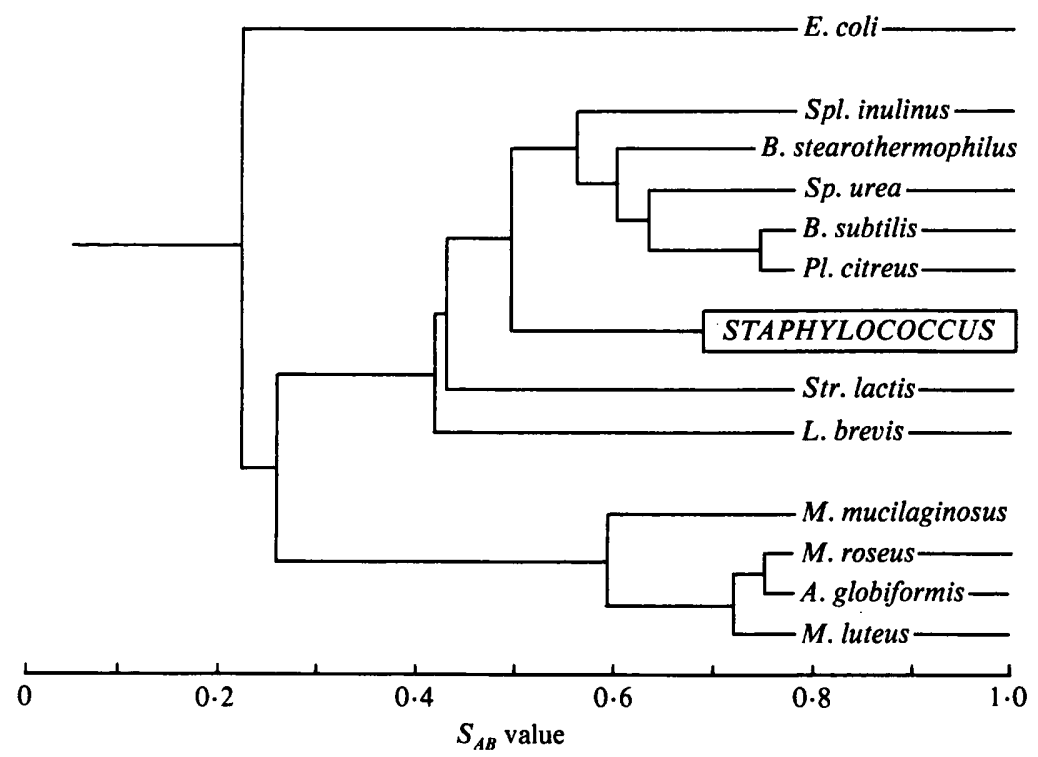

Fig. 1. Dendrogram showing the phylogenetic positions of the genus Staphylococcus and of Micrococcus mucilaginosus within the branch of the phylogenetic tree comprising Gram-positive organisms, derived by average linkage clustering. The Staphylococcus cluster contains $S$. xylosus DSM 20266, S. haemolyticus DSM 20263, S. aureus ATCC 12600, S. epidermidis ATCC 155, $S$. sciuri subsp. sciuri ATCC 29062 and Peptococcus saccharolyticus ATCC 14953. The following genus abbreviations are used: E., Escherichia; B., Bacillus; Spl., Sporolactobacillus; Sp., Sporosarcina; Pl., Planococcus; Str., Streptococcus; L., Lactobacillus; M., Micrococcus; A., Arthrobacter.

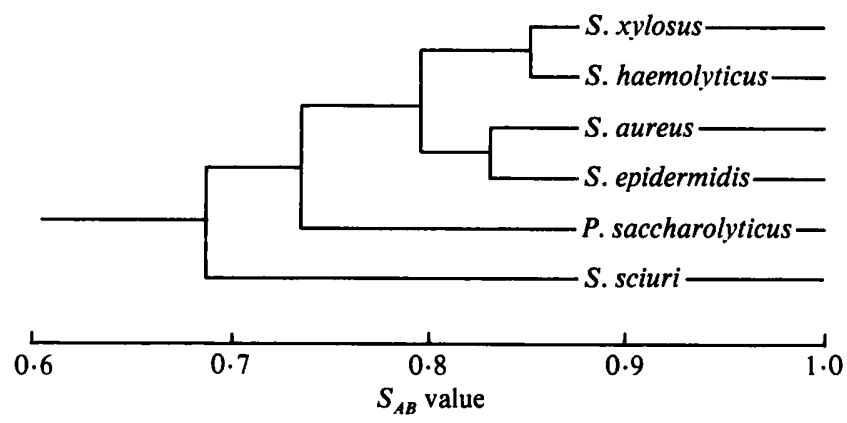

Fig. 2. Dendrogram showing the phylogenetic relationships between Staphylococcus xylosus, $S$. haemolyticus, $S$. aureus, $S$. epidermidis, $S$. sciuri subsp. sciuri and Peptococcus saccharolyticus, derived by average linkage clustering.

mucilaginosus (formerly Staphylococcus salivarius) CCM 2417 does not fall into the Arthrobacter/Micrococcus cluster, defined by Arthrobacter globiformis, M. roseus, M. luteus and their relatives (Stackebrandt et al., 1980). $S_{A B}$ values of 16S rRNA between $M$. mucilaginosus and organisms of this cluster range between 0.62 and 0.71 . These values, however, are lower than those found between species of the Arthrobacter/Micrococcus cluster $(0.71)$. The binary coefficients derived by average linkage clustering between $M$. mucilaginosus and representatives of the family I as proposed by Stackebrandt et al. (1980), which includes Cellulomonas, Brevibacterium, Microbacterium, Arthrobacter and Micrococcus, show that $M$. mucilaginosus is more distantly related $\left(S_{A B}\right.$ values ranging between 0.54 and 0.71 ). Thus the $S_{A B}$ value for the branching point of $M$. mucilaginosus from the main stem of the coryneform family $I$ is 0.59 . 


\section{Table 1. Oligonucleotide catalogues}

The sequences listed were found in the organisms indicated by the numbers: 1, Staphylococcus aureus ATCC 12600; 2, Peptococcus saccharolyticus ATCC 14953; 3, S. sciuri subsp. sciuri ATCC 29062; 4, S. xylosus DSM 20266; 5, S. haemolyticus DSM 20263; 6, S. epidermidis ATCC 155; 7, Micrococcus mucilaginosus CCM 2417.

$\begin{array}{ll}\text { Sequence } & \text { Organism } \\ \text { 6-mers } & \\ \text { CCCACG } & 1-6 \\ \text { CACAAG } & 1-7 \\ \text { AAACCG } & 1-6 \\ \text { ACAAAG } & 1,3-6 \\ \text { UCCACG } & 1-6 \\ \text { CUCACG } & 7 \\ \text { CAUCAG } & 7 \\ \text { CACUAG } & 7 \\ \text { CUAACG } & 1-7 \\ \text { ACUAAG } & 7 \\ \text { UAAACG } & 1-7 \\ \text { AAACUG } & 1-7 \\ \text { AAUACG } & 1-2,4-7 \\ \text { UUCCCG } & 1-7 \\ \text { CCUUCG } & 7 \\ \text { UCCAUG } & 7 \\ \text { CUCUAG } & 6 \\ \text { UCUCAG } & 7 \\ \text { UCUACG } & 7 \\ \text { UACCUG } & 7 \\ \text { ACUCUG } & 4,7 \\ \text { AUCCUG } & 1,4,6-7 \\ \text { UAACUG } & 1-7 \\ \text { UAAUCG } & 1-6 \\ \text { AUACUG } & 7 \\ \text { AAAUUG } & 7 \\ \text { UUUCCG } & 1-6 \\ \text { UCUUCG } & 1-4,6 \\ \text { UUCUAG } & 7 \\ \text { UCAUUG } & 1-6 \\ \text { UAUUAG } & 3-6 \\ & \end{array}$

\section{Sequence}

AACAAUAG

CCCCUUAG

CACUCUCG

ACCCUCUG

CCUAUCAG

UCAACUCG

AUACCCUG

UUCAACAG

CUACAAUG

ACUACAUG

ACUCAUAG

UUCAAAAG

AAAACUUG

AUAACAUG

CUCCUCUG

UUCUAAAG

UUCAAUAG

AAUUCCUG

UAACUAUG

ACUAUAUG

CUUCUCUG

CUCCUUUG

ACUUUCUG

AAUUAUUG

9-mers

CAACCCUCG

CUCACCAAG

CUACACACG

UACACACCG

UAACACCCG

AUCAAACAG

CCAUCUACG

CACUCUACG

ACUCCUACG

CUUACCAAG

CUCAAUCAG

CUAACUACG

CUAAUACCG

AUAACUCCG

CCCCUUAUG

CACAUCUUG

AAUCUUCCG

AAUUCCAUG

AUAACUUCG

AUUAAUUCG

UUUCUUAAG

UUUAAUUCG

UUUUUUAAG

10-mers

UCACACCACG

AAACUCAAAG

ACCCCUCUAG

ACCACUCUAG

CUUAACCCCG

ACAUUCCACG

CUAAUACCAG

ACAACUCUAG

ACAACUAUAG

AAAACUAUAG

ACAUCCUCUG

UCUAAUACCG

UAAACCUCUG

UAAAACUCUG
Organisms

1-6

3-5

7

1-7

$1,3-6$

7

1

$1-2,4,6$

2

2

5

3,6

7

2,4

2

1

4-6

1-2, 4-6

1-7

7

7

1-6

1-7

1-6

1-5

2

1,4

1-7

1-2, 4-6

3

1-7

1, 4-5

3

1-7

$1,5-6$

$1-6$

1-6

1-2, 4-6

7

3,5

$1-6$

$1-2,4,6$

$1-6$
$1-6$
2
3
7
7
2
1
4
5
2
7
7
$1-6$




\begin{tabular}{|c|c|c|c|}
\hline Sequence & Organisms & Sequence & Organisms \\
\hline ACAUAUACUG & 7 & 13-mers & \\
\hline AACAAAUUUG & 3 & CUAAAACUCAAAG & 7 \\
\hline ACAUCCUUUG & $1,3-6$ & UCAAAUCAUCAUG & $1-7$ \\
\hline UCACUUAUAG & $1-3,6$ & CUAUCACUUAUAG & $4-5$ \\
\hline UAACCAUUUG & 4 & CUAUCACUUAUAU & \\
\hline UUUCCCUUCG & 7 & 14-mers & \\
\hline UUUCCCUCUG & 7 & CAAACCCCAUAAAG & \\
\hline UAACCUUUUG & 2 & $\begin{array}{l}\text { CAAAUCCCAUAAAG } \\
\text { CUAAUCCCUAAAAG }\end{array}$ & $1,4-6$ \\
\hline \multicolumn{4}{|l|}{ 11-mers } \\
\hline AAUACACAAAG & 6 & 15 -mer & \\
\hline ACAAUACAAAG & $1-2,4-5$ & UAACCUACCUAUAAG & $3-5$ \\
\hline CAACCCUUAAG & $1-6$ & & \\
\hline ACCAAUCUCAG & 7 & 16-mer & \\
\hline UAACUAACCAG & 3 & AUAACCUACCUAUAAG & $1-2,6$ \\
\hline AUAAUACAAAG & 3 & & \\
\hline CUUAACACAUG & 7 & 17-mer & \\
\hline CCUAAUACAUG & $1-6$ & & $1-5$ \\
\hline CCAUCAUUAAG & $1-6$ & AACCUUACCAAAUCUUG & \\
\hline UACCUAAUCAG & $1-2,4-5$ & 18-mer & \\
\hline UACAAUACAUG & 1 & AACCUUACCAAAUCUUUG & 6 \\
\hline AUAACAUUUAG & 5 & AACCUUACCAAAUCUUUG & \\
\hline AUAAUAUUUCG & 4 & & \\
\hline \multirow[t]{2}{*}{ AUAAUAUUUUG } & 1,3 & 21-mers & \\
\hline & & CAAAUCCCAUAAAAUUAUACG & 3 \\
\hline 12-mers & & UCUUCCCCUUCUUUUUUAACG & 3 \\
\hline UAACACCCAAAG & 7 & $3^{\prime}$ end & \\
\hline $\begin{array}{l}\text { AACCUUACCAAG } \\
\text { UCUUCCCCUUCG }\end{array}$ & $\begin{array}{l}7 \\
6\end{array}$ & AUCACCUCCUUUCU ${ }_{\mathrm{OH}}$ & $1-6$ \\
\hline CCUAACCUUUUG & 7 & AUCACCUCCUUUCU & $7^{\dagger}$ \\
\hline UAACCAUUUAUG & $5-6$ & & \\
\hline UUUUCCCCUUCG & 2 & Modified oligonucleotide & \\
\hline UAACCUUUUCUG & 1,3 & ÜAACAAG & $1-7$ \\
\hline
\end{tabular}

+ For differences in the ...(C)CCUUU ... portion in the $3^{\prime}$ end of the $16 \mathrm{~S}$ rRNA from members of the actinomyces group and from non-actinomyces organisms, see Stackebrandt et al. (1980).

\section{DISCUSSION}

Comparative oligonucleotide cataloguing of 16S rRNA using the in vitro labelling procedure described by Stackebrandt et al. (1981) corroborates the high level of relatedness among the staphylococci as previously demonstrated by DNA-DNA reassociation experiments (Meyer \& Schleifer, 1978; Kloos \& Wolshohl, 1979; Rosenblum \& Tyrone, 1979; Schleifer et al., 1979a; Goodfellow et al., 1980) and comparative immunological studies (Rupprecht \& Schleifer, 1979; Schleifer et. al., 1979a). A comparison of DNA-DNA homology values and $S_{A B}$ values is given in Table 3. It should be noted that Staphylococcus epidermidis ATCC 155 does not fit the description for $S$. epidermidis sensu stricto (Schleifer \& Kocur, 1973; Schleifer \& Kloos, 1975): it differs in several biochemical characters from a typical $S$. epidermidis and more closely resembles $S$. warneri. However, DNA-DNA reassociation studies established that $S$. epidermidis and $S$. warneri, together with $S$. capitis, form a closely related species group (Schleifer et al., 1979a). The closer relationship of $S$. epidermidis/S. warneri to $S$. haemolyticus, as determined by DNA homologies, was not detected by the analysis of their RNAs. According to the $S_{A B}$ values, $S$. haemolyticus is more closely related to $S$. xylosus $(0.85)$ than to $S$. epidermidis/S. warneri $(0.81)$. These differences may be explained by the highly conserved DNA sequence of the 16S rRNA cistrons, which certainly does not reflect actual changes in the base sequences of the bulk of less-conserved genes. The distinction of coagulase-positive staphylococci ( $S$. aureus) from the coagulase-negative species is more of clinical diagnostic value than of taxonomic significance. As previously demonstrated, $S$. aureus does not show separate grouping from the coagulase-negative strains but is phylogenetically closely related to them (Meyer \& Schleifer, 1978; Schleifer et al., $1979 a$; Rosenblum \& Tyrone, 1979). 
Table 2. Binary comparison of $16 S$ rRNA catalogues

The number in the upper left of each rectangle is the $S_{A B}$ value for that pair of catalogues; the number in the lower right corner is the number of bases common to that pair of catalogues (for hexamers and larger oligonucleotides). The catalogues of oligonucleotides of 16S rRNA for the reference organisms not listed in Table 1 are from the following sources: Uchida et al. (1974) for Escherichia coli; Fox et al. (1977) for Bacillus subtilis, B. stearothermophilus, Sporosarcina urea, Sporolactobacillus inulinus; Stackebrandt \& Woese (1979) for Planococcus citreus; Stackebrandt et al. (1980) for Micrococcus luteus, M. roseus, Arthrobacter globiformis. The catalogues of Streptococcus lactis and Lactobacillus brevis are from unpublished results of C. R. Woese and E. Stackebrandt.

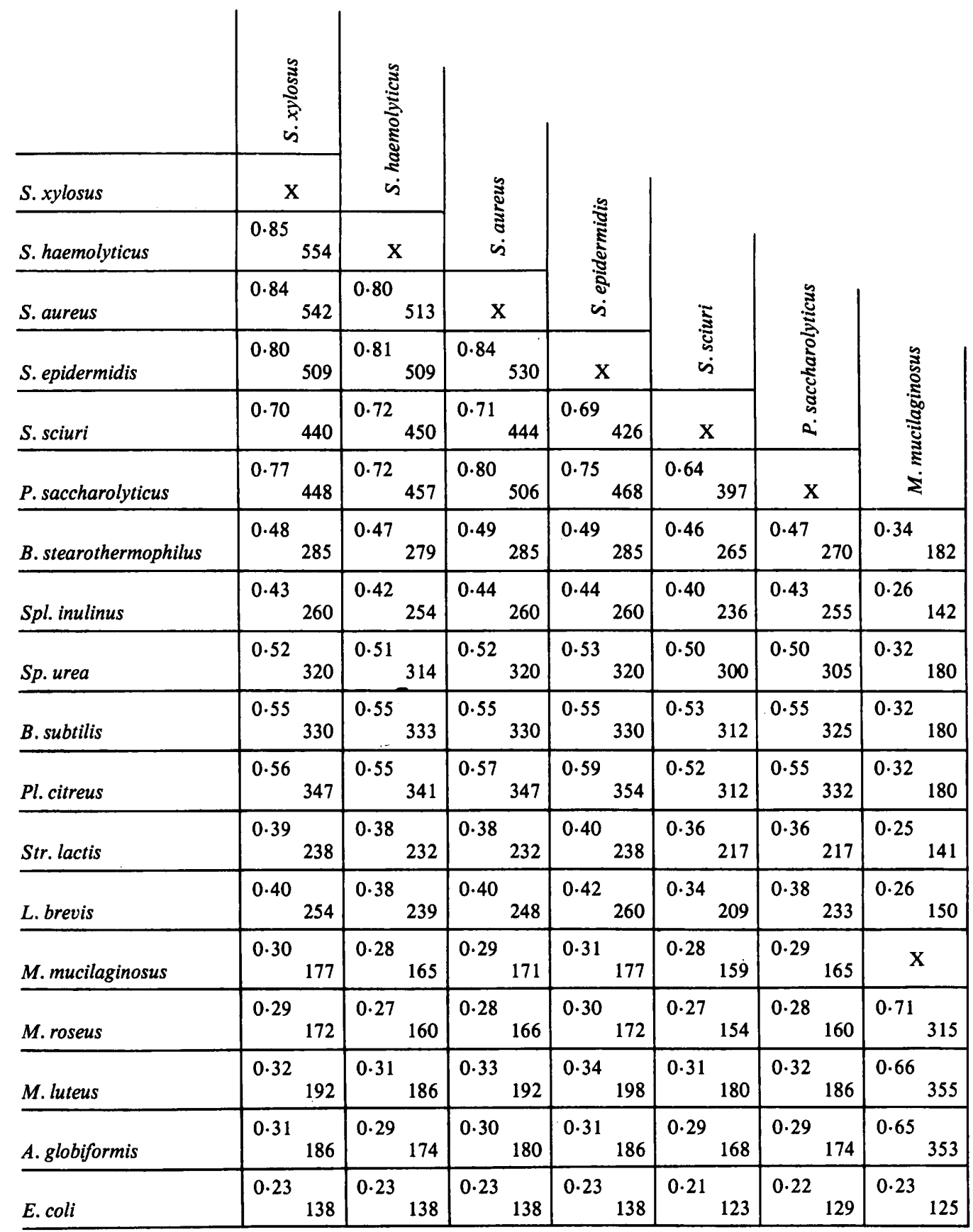


Table 3. Comparison of DNA-DNA homology values and $S_{A B}$ values for each pair of

\begin{tabular}{|c|c|c|c|c|c|c|}
\hline$\underbrace{\begin{array}{c}\text { DNA-DNA } \\
\text { homology }(\%) \dagger\end{array}}_{S_{A B} \text { value }}$ & 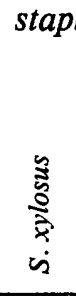 & 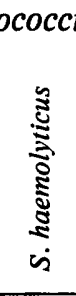 & 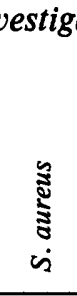 & 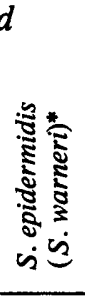 & 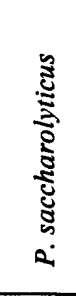 & 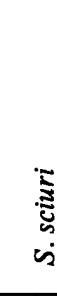 \\
\hline S. xylosus & $\mathrm{X}$ & $\begin{array}{l}25^{a} \\
33^{c} \\
25^{e}\end{array}$ & $\begin{array}{l}23^{a} \\
27^{b}\end{array}$ & $\begin{array}{l}27^{a} \\
32^{c}\end{array}$ & $20^{d}$ & ND \\
\hline S. haemolyticus & 0.85 & $\mathbf{x}$ & $\begin{array}{l}14^{b} \\
32^{e}\end{array}$ & $\begin{array}{l}40^{a} \\
45^{c} \\
39^{e}\end{array}$ & $32^{d}$ & $22^{e}$ \\
\hline S. aureus & 0.84 & 0.80 & $\mathrm{X}$ & $\begin{array}{l}32^{a} \\
25^{b}\end{array}$ & $24^{d}$ & $15^{b}$ \\
\hline $\begin{array}{c}\text { S. epidermidis } \\
\text { (S. warneri) }\end{array}$ & 0.80 & 0.81 & 0.84 & $\mathrm{x}$ & $29^{d}$ & ND \\
\hline P. saccharolyticus & 0.77 & 0.72 & 0.80 & 0.75 & $\mathrm{x}$ & $15^{d}$ \\
\hline S. sciuri & 0.70 & 0.72 & 0.71 & 0.69 & 0.64 & $\mathbf{x}$ \\
\hline
\end{tabular}

ND, Not determined.

* See Discussion.

$\dagger a$, Membrane filter technique, $29^{\circ} \mathrm{C}$ below $T_{m}$ (Schleifer et al., 1979a,b); b, hydroxyapatite at $55^{\circ} \mathrm{C}$ (Rosenblum \& Tyrone, 1979); $c$, membrane filter technique, $25^{\circ} \mathrm{C}$ below $T_{m}$ (Goodfellow et al., 1980); $d$, membrane filter technique, $25^{\circ} \mathrm{C}$ below $T_{m}$ (Kilpper et al., 1980); e, hydroxyapatite at $55^{\circ} \mathrm{C}$ (Kloos \& Wolshohl, 1979).

Peptococcus saccharolyticus, originally described as a member of the genus Peptococcus (Foubert \& Douglas, 1948), was later removed from this genus when its saccharoclastic properties were detected. In the latest edition of Bergey's Manual (Rogosa, 1974), P. saccharolyticus is listed as species incertae sedis. The first indication of a relationship of this species to Staphylococcus was given by the similarity in the peptidoglycan type (Schleifer \& Nimmermann, 1973). Later, Kilpper \& Schleifer (1978) and Crosa et al. (1979) found a significant degree of relationship of $P$. saccharolyticus to coagulase-negative staphylococci, based on DNA-DNA homology studies. More extensive nucleic acid reassociation studies using DNA-DNA and DNA-23S rRNA hybridization techniques established the close genetic relatedness of $P$. saccharolyticus to the staphylococci (Kilpper et al., 1980). This finding is confirmed by our results.

A comparative immunological study between antisera against highly purified catalases of $S$. epidermidis, $S$. capitis and $S$. xylosis and crude extract of $S$. sciuri subsp. sciuri ATCC 29062 demonstrated $S$. sciuri to be the most distantly related species within Staphylococcus (Schleifer et al., 1979a). Although the cell wall composition of S. sciuri is typical of staphylococci (Kloos et al., 1976), its cytochrome patterns are different (Faller et al., 1980). Numerical taxonomic studies (Feltham, 1979) placed strains of $S$. sciuri even more distant from staphylococci and micrococci than these latter two groups are from each other. This led to a proposal to place $S$. sciuri and its relatives into a new genus named Cellobiosococcus, because its members produce acid aerobically from cellobiose. This ability, however, is not restricted to $S$. sciuri, but was recently found also in strains of $S$. xylosus 
(Bucher et al., 1980). The analysis of the 16S rRNA of $S$. sciuri clearly establishes a close phylogenetic relatedness to Staphylococcus species. Staphylococcus sciuri does, however, represent an early branching among these staphylococci and thus it exhibits significant phenotypic differences.

Within the branch of the prokaryotic phylogenetic tree (Fox et al., 1980) comprising Gram-positive bacteria, the staphylococci are found within the Bacillus cluster (Fig. 1). This cluster contains a variety of morphologically different Gram-positive bacteria such as Sporosarcina urea (Pechman et al., 1976), Planococcus citreus (Stackebrandt \& Woese, 1979) and Thermoactinomyces vulgaris (Fox et al., 1980). Furthermore, the Bacillus cluster includes not only aerobic but also facultative anaerobic or microaerophilic organisms, e.g. Bacillus polymyxa and Peptococcus saccharolyticus. Further support for the relatedness of staphylococci and bacilli is the fact that the DNA G+C content of Staphylococcus (32 to $38 \mathrm{~mol} \%$; Schleifer et al., 1979a) lies within the range for Bacillus (32 to $53 \mathrm{~mol} \%$, except for $B$. acidocaldarius for which a value of $62 \mathrm{~mol} \%$ is reported; Jones \& Sneath, 1970; Gibson \& Gordon, 1974) and that purified plasmid DNA coding for drug resistance, and also crude extract of $S$. aureus, can transform B. subtilis (Ehrlich, 1977; Feitelson \& Lederberg, 1980).

The $S_{A B}$ value for the branching point of the Staphylococcus cluster from the main stem of Bacillus is about 0.5 . The separation of Staphylococcus from microaerophilic or aerotolerant Gram-positive bacteria like lactobacilli and Streptococcus lactis occurs at an $S_{A B}$ value of about 0.42 (Fox et al., 1980). However, more RNA sequencing studies of different streptococci are necessary to prove the coherency of the genus Streptococcus, as well as to find the branching point of this genus within the Bacillus/Staphylococcus-StreptococcusLactobacillus cluster. Transferability of plasmids between various streptococci and $S$. aureus (Engel et al., 1980) indicates a natural relationship between these bacteria.

The classification of Micrococcus mucilaginosus as a member of the genus Micrococcus is now seen to be unjustified. Spherical shape and superficial resemblance in simple physiological characteristics as detected in numerical taxonomic studies on micrococci (Feltham, 1979) are not sufficient grounds for classifying an organism as Micrococcus. A similar case was recently seen with the radiation-resistant species $M$. radiodurans and $M$. radiophilus (Brooks et al., 1980). The separation of $M$. mucilaginosus from the genuine micrococci is further supported by differences in DNA G+C content of about 10 mol \% (59 mol \% for M. mucilaginosus versus 68 to $72 \mathrm{~mol} \%$ for Micrococcus). According to Sueoka (1961) two strains differing by more than $10 \mathrm{~mol} \%$ cannot be phylogenetically closely related. A difference of more than $5 \mathrm{~mol} \%$ has usually been interpreted as implying membership of a different genus (De Ley, 1969). The characterization of its 16S rRNA clearly reveals that $M$. mucilaginosus belongs to a new genus yet to be described. This genus belongs to a larger group of genera (Arthrobacter, Micrococcus, Brevibacterium, Cellulomonas and Microbacterium) for which the status of a family was recently suggested (Stackebrandt et al., 1980).

Our results demonstrate the advantage of the combined application of nucleic acid reassociation studies and the comparative analysis of 16S rRNA for phylogenetic studies. DNA-DNA homology studies allow investigation of a larger number of organisms within a short period. However, this method is restricted to closely related species, and fails among more remotely related species, as shown in studies on bacilli (Seki et al., 1975), micrococci (Ogasawara-Fujita \& Sakaguchi, 1976; Schleifer et al., 1979b) and arthrobacters (Stackebrandt \& Fiedler, 1979). DNA-rRNA reassociation studies may be useful for studying less related species since this method permits the elucidation of genetic relationships even at the intergeneric level (Johnson \& Francis, 1975; De Smedt \& De Ley, 1977). The comparative analysis of $16 \mathrm{~S}$ rRNA is an excellent tool for studying the relatedness not only of closely related species (Pechman et al., 1976; Stackebrandt et al., 1980) but also of distantly related bacteria (Woese \& Fox, 1977). The advantage of investigating the 16S 
rRNA from representatives of genetic clusters, defined either as a genus or a family by nucleic acid homology studies, is that the entire cluster can at once be placed into the existing phylogenetic tree of prokaryotes.

We wish to thank Professor H.-J. Gross for the use of part of his laboratory facilities at the Max-Planck Institute for Biochemistry, München, Martinsried. The work reported here was supported by a grant from the Deutsche Forschungsgemeinschaft and by N.A.S.A. Grant NSG 7440 to G.E.F.

\section{RE F ER E N CES}

BAIRD-PARKER, A. C. (1974). Micrococcaceae. In Bergey's Manual of Determinative Bacteriology, 8th edn, pp. 478-490. Edited by R. E. Buchanan \& N. E. Gibbons. Baltimore: Williams \& Wilkins.

Brooks, B. W., Murray, R. G. E., Johnson, J. L., STACKebrandT, E., WoEse, C. R. \& Fox, G. E. (1980). Red-pigmented micrococci: a basis for taxonomy. International Journal of Systematic Bacteriology 30, 627-646.

Bucher, E., Beck, G. \& Schleifer, K. H. (1980). Occurrence and distribution of staphylococci and micrococci in soybean oil meal. Zentralblatt für Bakteriologie (Abteilung I, Originale C) 1, 320-329.

Crosa, J. H., Williams, B. L., Jorgensen, J. J. \& Evans, C. A. (1979). Comparative study of deoxyribonucleic acid homology and physiological characteristics of strains of Peptococcus saccharolyticus. International Journal of Systematic Bacteriology 29, 328-332.

DE LEY, J. (1969). Compositional nucleotide distribution and the theoretical prediction of homology in bacterial DNA. Journal of Theoretical Biology 22, 89-116.

De Smedt, J. \& DE LEY, J. (1977). Intra- and intergeneric similarities of Agrobacterium ribosomal ribonucleic acid cistrons. International Journal of Systematic Bacteriology 27, 222-240.

EHRLICH, S. D. (1977). Replication and expression of plasmids from Staphylococcus aureus in Bacillus subtilis. Proceedings of the National Academy of Sciences of the United States of America 74, 1680-1682.

Engel, H. W. B., Soedirman, N., Rost, J. A., Van LeEuwen, W. J. \& VAN Embden, J. D. A. (1980). Transferability of macrolide, lincomycin, and streptogramin resistances between group A, B and D streptococci, Streptococcus pneumoniae, and Staphylococcus aureus. Journal of Bacteriology 142, 407-413.

FAller, A. H., Götz, F. \& Schleifer, K. H. (1980). Cytochrome-patterns of staphylococci and micrococci and their taxonomic implications. Zentralblatt für Bakteriologie (Abteilung I, Originale C) 1, 26-39.

Feitelson, J. S. \& Lederberg, J. (1980). Crude lysates of Staphylococcus aureus can transform Bacillus subtilis. Journal of General Microbiology 116, 545-547.

Feltham, R. K. A. (1979). A taxonomic study of the Micrococcaceae. Journal of Applied Bacteriology 47, 243-254.

Foubert, E. L. \& Douglas, H. G. (1948). Studies on the anaerobic micrococci. Journal of Bacterio$\log y 56,25-34$.
Fox, G. E., Pechman, K. R. \& Woese, C. R. (1977). Comparative cataloging of $16 \mathrm{~S}$ ribosomal ribonucleic acid: molecular approach to procaryotic systematics. International Journal of Systematic Bacteriology 27, 44-57.

Fox, G. E., Stackebrandt, E., Hespell, R. B., Gibson, J., Maniloff, J., Dyer, T. A., Wolfe, R. S., Balch, W. E., TANNER, R. S., MAGrum, L. J., Zablen, L. B., Blakemore, R., Gupta, R., Bonen, L., Lewis, B. J., Stahl, D. A., Luehrsen, K. R., Chen, K. N. \& Woese, C. R. (1980). The phylogeny of prokaryotes. Science 209, 457-463.

Gibson, T. \& GoRdoN, R. E. (1974). Bacillus. In Bergey's Manual of Determinative Bacteriology, 8th edn, pp. 529-550. Edited by R. E. Buchanan \& N. E. Gibbons. Baltimore: Williams \& Wilkins.

Goodfellow, M., Mordarski, M., TKaCZ, A., Szyba, K. \& Pulverer, G. (1980). Polynucleotide sequence divergence among some coagulasenegative staphylococci. Zentralblatt für Bakteriologie (Abteilung I, Originale A) 246, 10-22.

JohnSON, J. L. \& FRANCIS, B. S. (1975). Taxonomy of the clostridia: ribosomal ribonucleic acid homologies among the species. Journal of General Microbiology 88, 229-244.

JoNES, D. \& SNEATH, P. H. A. (1970). Genetic transfer and bacterial taxonomy. Bacteriological Reviews 34, 40-81.

KIlPPER, R. \& Schleifer, K. H. (1978). Peptococcus saccharolyticus: an anaerobic Staphylococcus? In Abstracts of the XII International Congress of Microbiology, p. 86, С6.

KILPPER, R., BUHL, U. \& SCHLEIFER, K. H. (1980). Nucleic acid homology studies between Peptococcus saccharolyticus and various anaerobic and facultative anaerobic Gram-positive cocci. FEMS Microbiology Letters 8, 205-210.

KLoos, W. E. \& WolshoнL, J. F. (1979). Evidence for deoxyribonucleotide sequence divergence between staphylococci living on human and other primate skin. Current Microbiology 3, 167-172.

Kloos, W. E., Schleifer, K. H. \& Smith, R. F. (1976). Characterization of Staphylococcus sciuri sp. nov. and its subspecies. International Journal of Systematic Bacteriology 26, 22-37.

KOCUR, M. \& BOHACEK, J. (1974). DNA base composition and the classification of non-pigmented micrococci. Microbios 10A, 31-38.

Kocur, M., Bergan, T. \& Mortensen, N. (1971). DNA base composition of Gram-positive cocci. Journal of General Microbiology 69, 167-183.

Meyer, S. A. \& SchleIfER, K. H. (1978). Deoxyribonucleic acid reassociation in the classification of coagulase-positive staphylococci. 
Archives of Microbiology 117, 183-188.

Ogasawara-Fujita, N. \& Sakaguchi, K. (1976). Classification of micrococci on the basis of deoxyribonucleic acid homology. Journal of General Microbiology 94, 97-106.

Pechman, K. J., Lewis, B. J. \& Woese, C. R. (1976). Phylogenetic status of Sporosarcina urea. International Journal of Systematic Bacteriology 26, 305-310.

RogosA, M. (1974). Peptococcus. In Bergey's Manual of Determinative Bacteriology, 8th edn., pp. 518522. Edited by R. E. Buchanan \& N. E. Gibbons, Baltimore: Williams \& Wilkins.

Rosenblum, E. D. \& TYRONE, S. (1979). Deoxyribonucleic acid homologies among staphylococci: coagulase-positive reference strains. Current Microbiology 2, 171-174.

RUPPRECHT, M. \& SCHLEIFER, K. H. (1979). A comparative immunological study of catalases from coagulase-positive staphylococci. Archives of Microbiology 120, 53-56.

SCHLEIFER, K. H. \& KANDLER, O. (1972). The peptidoglycan types of bacterial cell walls and their taxonomic implications. Bacteriological Reviews 36, 407-477.

SchleIFER, K. H. \& KLoos, W. E. (1975). Isolation and characterization of staphylococci from human skin. I: Amended description of Staphylococcus epidermidis and Staphylococcus saprophyticus, and description of three new species: Staphylococcus cohnii, Staphylococcus haemolyticus and Staphylococcus xylosus. International Journal of Systematic Bacteriology 25, 50-61.

SCHLEIFER, K. H. \& KOCUR, M. (1973). Classification of staphylococci based on chemical and biochemical properties. Archives of Microbiology 93, 65-85.

SCHLEIFER, K. H. \& NimMERMANN, E. (1973). Peptidoglycan types of strains of the genus Peptococcus. Archiv für Mikrobiologie 93, 245-258.

SCHLEIFER, K. H., MEYER, S. A. \& RUPPRECHT, M. $(1972 a)$. Relatedness among coagulase-negative staphylococci: deoxyribonucleic acid reassociation and comparative immunological studies. Archives of Microbiology 122, 93-101.

SCHLeIfER, K. H., MEYeR, S. A. \& HeISE, W. $(1979 b)$. Deoxyribonucleic acid hybridization studies among some micrococci. FEMS Microbiology Letters 6, 33-36.

Seki, T., Oshima, T. \& Oshima, Y. (1975). Taxonomic study of Bacillus by deoxyribonucleic aciddeoxyribonucleic acid hybridization and inter- specific transformation. International Journal of Systematic Bacteriology 25, 258-270.

Silberklang, M., Gillum, A. M. \& Rajbhandary, U. L. (1979). Use of in vitro ${ }^{32} \mathrm{P}$ labelling in the sequence analysis of nonradioactive tRNAs. Methods in Enzymology 59G, 58-109.

Silvestri, L. G. \& HiLl, L. R. (1965). Agreement between deoxyribonucleic acid base composition and taxometric classification of Gram-positive cocci. Journal of Bacteriology 90, 136-140.

Simsek, M., Ziegenmeyer, J., Heckman, J. E. \& RAJBHANDARY, U. L. (1973). Absence of the sequence -G-T- $\Psi-C-G$ - in several eukaryotic cytoplasmic initiator transfer RNAs. Proceedings of the National Academy of Sciences of the United States of America 70, 1041-1045.

StACKebrandT, E. \& Fiedler, F. (1979). DNADNA homology studies among strains of Arthrobacter and Brevibacterium. Archives of Microbiology 120, 289-295.

StackebrandT, E. \& WoEse, C. R. (1979). A phylogenetic dissection of the family Micrococcaceae. Current Microbiology 2, 317-322.

StackebrandT, E., Lewis, B. J. \& Woese, C. R. (1980). The phylogenetic structure of the coryneform group of bacteria. Zentralblatt für Bakteriologie (Abteilung I, Originale C) 1, 137-149.

StaCKebrandt, E., LUdWig, W., Schleifer, K. H. \& Gross, H. J. (1981). Rapid cataloging of ribonuclease $T_{1}$ resistant oligonucleotides from ribosomal RNAs for phylogenetic studies. Journal of Molecular Evolution 17 (in the Press).

SUEOKA, N. (1961). Variation and heterogeneity of base composition of deoxyribonucleic acids: a compilation of old and new data. Journal of Molecular Biology 3, 31-40.

Uchida, T., Bonen, L., Schaup, H. W., Lewis, B. J., ZABLEN, L. \& WOESE, C. R. (1974). The use of ribonuclease $\mathrm{U}_{2}$ in RNA sequence determination. Journal of Molecular Evolution 3, 63-77.

WoEse, C. R. \& Fox, G. E. (1977). Phylogenetic structure of the prokaryotic domain. The primary kingdoms. Proceedings of the National Academy of Sciences of the United States of America 74, 5088-5090.

Woese, C. R., Sogin, M., Stahl, D., Lewis, B. J. \& BONEN, L. (1976). A comparison of the $16 \mathrm{~S}$ ribosomal RNAs from mesophilic and thermophilic bacilli: some modifications in the Sanger method for RNA sequencing. Journal of Molecular Evolution 7, 197-213. 